\title{
Sewage sludge compost as a substrate for croton seedlings production ${ }^{(1)}$
}

\author{
MARCELA CAETANO LOPES (2)*, CAROLINE DE MOURA D'ANDRÉA MATEUS ${ }^{(2)}$ \\ DÁVILLA ALESSANDRA DA SILVA ALVES ${ }^{(2)}$, ARMANDO REIS TAVARES(3), \\ LUIZ VITOR CREPALDI SANCHES ${ }^{(4)}$, ROBERTO LYRA VILLAS BÔAS ${ }^{(2)}$
}

\begin{abstract}
The floricultural industry is always searching for new and low-cost materials to use as substrate for crop growth and development. Sewage sludge is an organic solid waste from sewage treatment and it has a good potential to be used as an organic fertilizer and/or substrate conditioner. The research aimed to evaluate the rooting and growth of Codiaeum variegatum 'Andreanum' (red variety) and Codiaeum variegatum 'Punctatum' (yellow variety) cuttings cultivated in the potting media: PM1 - 100\% commercial potting media used as control (CS), PM2 - 100\% organic compost of sewage sludge + sugarcane bagasse (SSSB), PM3 - 50\% CS + 50\% SSSB, PM4 - 100\% organic compost of sewage sludge + eucalyptus bark (SSEB) and PM5 - 50\% CS + 50\% SSEB. After 90 days of experimentation the chemical analysis of the substrate solution ( $\mathrm{pH}$, electric conductivity, $\mathrm{P}, \mathrm{K}, \mathrm{Ca}, \mathrm{Mg}, \mathrm{S}, \mathrm{Na}, \mathrm{B}, \mathrm{Cu}, \mathrm{Mn}$ and $\mathrm{Zn}$ ) and number of shoots, shoot fresh and dry mass, plant cutting fresh and dry masses, root fresh and dry masses, total fresh and dry masses and, length of the largest root were analyzed. Our results showed that sewage sludge compost can be used as a substrate for rooting and growth of croton cuttings when mixed with commercial substrate. The use of the pure sewage sludge compound with sugarcane bagasse or eucalyptus bark prejudiced croton cuttings to root.
\end{abstract}

Keywords: organic fertilization, composting, organic waste.

\section{RESUMO}

Composto de lodo de esgoto como substrato para produção de mudas de cróton

A floricultura está sempre em busca de materiais novos e de baixo custo para serem utilizados como substrato para o cultivo de plantas. Lodo de esgoto é um resíduo sólido orgânico do tratamento de esgoto e pode ser utilizado como fertilizante orgânico e condicionador de substrato. Objetivou-se avaliar o uso de lodo de esgoto na produção de mudas dos crótons Codiaeum variegatum 'Andreanum' (variedade vermelha) e Codiaeum variegatum 'Punctatum' (variedade amarela) cultivadas nos substratos: PM1 $100 \%$ de substrato comercial usado como controle (CS), PM2 - 100\% de composto orgânico com lodo de esgoto + bagaço de cana-de-açúcar (SSSB), PM3 - 50\% CS + 50\% SSSB, PM4 - 100\% de composto orgânico com lodo de esgoto + casca de eucalipto (SSEB) e PM5 - 50\% CS + 50\% SSEB. O delineamento experimental utilizado foi o fatorial inteiramente casualizado $5 \times 2$ (substratos x variedades). Após 90 dias de experimentação foram analisados a composição química da solução do substrato (pH, condutividade elétrica, $\mathrm{P}, \mathrm{K}, \mathrm{Ca}, \mathrm{Mg}, \mathrm{S}, \mathrm{Na}, \mathrm{B}, \mathrm{Cu}, \mathrm{Mn}$ e $\mathrm{Zn}$ ) e o número de brotações, massa fresca e seca da parte aérea, massa fresca e seca das estacas, massa fresca e seca das raízes, massa fresca e seca total e comprimento da maior raiz. O composto de lodo de esgoto pode ser utilizado apenas em combinação com o substrato comercial. O uso do composto de lodo de esgoto misturado com bagaço de cana ou casca de eucalipto prejudica o enraizamento de estacas de cróton.

Palavras-chave: adubação orgânica, compostagem, resíduo orgânico.

\section{INTRODUCTION}

Sewage sludge is an organic solid waste from the treatment of sewage from sewage treatment plants (STP). The material is rich in organic matter and its use in agriculture as organic composite fertilizer is regulated by the Decree $4.954 / 2004$ and limited by Resolutions 375/2006, 380/2006 and 481/2017 (CONAMA) and by Normative Instructions 27/2006 and 25/2009 (MAPA).

Currently the agricultural recycling is the most important destination for sewage sludge, once the material is rich in nutrients, consequently an excellent organic fertilizer (CONTIN et al., 2012), and has shown to increase production on several crops (SILVA et al., 2010). Sewage sludge can improve soil fertility by increasing CTC when incorporated into the soil, reducing concentrations of exchangeable aluminum and as a source of macro and micronutrients for plants (PRADO and CUNHA, 2011). Sewage sludge is also a soil conditioner due to its organic constitution improving soil particles aggregation and, consequently, increasing aeration and water retention capacity of the soils. In addition, sewage sludge may

\footnotetext{
DoI: http://dx.doi.org/10.14295/oh.v24i4.1234

${ }^{(1)}$ Received in 04/06/2018 and accepted in 27/09/2018

(2) Universidade Estadual Paulista (UNESP), Departamento de Solos e Recursos Ambientais (FCA), Botucatu-SP, Brazil. *Corresponding author: macaetano20@hotmail.com

${ }^{(3)}$ Instituto de Botânica, São Paulo-SP, Brazil.

(4) Faculdades Integradas de Bauru (FIB), Bauru-SP, Brazil.

Licensed by CC BY 4.0
} 
increase soil microbial activity, which improves the physical and biological attributes of soils (WILSON et al., 1996; GALDOS et al., 2004, PRADO and CUNHA, 2011).

Croton (Codiaeum variegatum) is one of the most popular indoor plants, due to its adaptation to shade conditions and the variety of leaf shapes and color range (YOUNIS et al., 2010). Many species of croton are known for the brightly colored foliage ranging from red, orange and yellow, to green, with all combinations of variegated mixtures (MAHESH, et al., 2010). Croton plants are hardy, usually unaffected by insects and diseases, and highly adaptable to a wide range of environmental conditions and climate trends; which makes it recommended to be used as indoor plants for homes and buildings, potted plants, and by florists as fillers or greens in floral arrangements and bouquets (MAGDALITA et al., 2014).
This study aimed to evaluate the efficiency of sewage sludge on production of croton plantlets.

\section{MATERIAL AND METHODS}

The research was conducted in a plastic greenhouse $\left(22^{\circ} 51^{\prime} \mathrm{S}\right.$ and $\left.48^{\circ} 26^{\prime} \mathrm{W}\right)$ with an automated nebulizer irrigation system.

The treatments were composed of the potting media: PM1 - 100\% commercial potting media used as control (CS), PM2 - 100\% organic compost of sewage sludge + sugarcane bagasse (SSSB), PM3 - 50\% CS + 50\% SSSB, PM4 - 100\% organic compost of sewage sludge + eucalyptus bark (SSEB) and PM5 - 50\% CS + 50\% SSEB. Tables 1 and 2 contents the chemical and granulometric characteristics of each potting media.

Table 1. Chemical characteristics of samples from each potting media used as treatment.

\begin{tabular}{|c|c|c|c|c|c|c|c|c|c|c|c|c|c|}
\hline \multirow{2}{*}{$\begin{array}{l}\text { Potting } \\
\text { media }\end{array}$} & \multirow[t]{2}{*}{ pH } & EC & $\mathbf{P}$ & $\mathbf{K}$ & Ca & Mg & $\mathbf{S}$ & $\mathrm{Na}$ & B & $\mathrm{Cu}$ & $\mathrm{Fe}$ & Mn & \multirow[t]{2}{*}{$\mathrm{Zn}$} \\
\hline & & $\mathrm{mS} \mathrm{cm} \mathrm{cm}^{-1}$ & & \multicolumn{9}{|c|}{ mg L } & \\
\hline PM1 & 6.1 & 1.4 & 27.3 & 83.4 & 27.0 & 56.1 & 67.1 & 19.9 & 0.11 & 0.04 & 0.1 & 0.3 & 0.14 \\
\hline PM2 & 6.2 & 0.7 & 1.2 & 41.1 & 139.9 & 29.0 & 497.5 & 17.9 & 0.04 & 0.04 & 1.8 & 0.6 & 0.12 \\
\hline PM3 & 6.1 & 0.5 & 3.1 & 56.8 & 123.8 & 87.2 & 422.7 & 22.9 & 0.05 & 0.04 & 0.4 & 0.7 & 0.17 \\
\hline PM4 & 6.1 & 0.8 & 0.8 & 40.6 & 153.9 & 29.8 & 441.4 & 15.6 & 0.03 & 0.04 & 1.1 & 0.9 & 0.10 \\
\hline PM5 & 6.1 & 0.5 & 1.3 & 49.8 & 142.1 & 64.3 & 308.0 & 16.3 & 0.03 & 0.02 & 0.5 & 0.8 & 0.12 \\
\hline
\end{tabular}

PM1 - 100\% CS, PM2 - 100\% SSSB, PM3 - 50\% CS + 50\% SSSB, PM4 - 100\% SSEB, PM5 - 50\% CS + 50\% SSEB, CS: commercial substrate, SSSB: organic compost with sewage sludge + sugarcane bagasse, SSEB: organic compost with sewage sludge + eucalyptus bark.

Table 2. Granulometric characteristics of samples from each potting media used as treatment.

\begin{tabular}{|ccccccc|}
\hline & \multicolumn{7}{c|}{ Percentage (\%) retained in the sieves (mm) } \\
\hline Potting media & $\mathbf{4 . 8}$ & $\mathbf{3 . 3 6}$ & $\mathbf{2 . 8 3}$ & $\mathbf{2 . 0}$ & $\mathbf{1 . 0}$ & $\mathbf{0 . 5}$ \\
\hline PM1 & 0.2 & 1.2 & 3.8 & 13.0 & 61.2 & 88.9 \\
\hline PM2 & 21.6 & 28.5 & 33.1 & 39.1 & 51.5 & 70.9 \\
\hline PM3 & 9.9 & 15.6 & 19.6 & 26.6 & 50.0 & 79.7 \\
\hline PM4 & 1.5 & 7.2 & 13.2 & 22.9 & 44.4 & 66.6 \\
\hline PM5 & 2.1 & 7.4 & 13.1 & 23.5 & 53.6 & 80.0 \\
\hline
\end{tabular}

PM1 - 100\% CS, PM2 - 100\% SSSB, PM3 - 50\% CS + 50\% SSSB, PM4 - 100\% SSEB, PM5 - 50\% CS + 50\% SSEB, CS: commercial substrate, SSSB: organic compost with sewage sludge + sugarcane bagasse, SSEB: organic compost with sewage sludge + eucalyptus bark.

The croton varieties used on the experiment were Codiaeum variegatum 'Andreanum' (red variety) and Codiaeum variegatum 'Punctatum' (yellow variety). Cuttings of both varieties, with no leaves, $15 \mathrm{~cm}$ height and diameter of 6.5-7.0 and 4.5 and 5.0 for 'Andreanum' and
'Punctatum', respectively were used. The cuttings were set at $5 \mathrm{~cm}$ down the potting media $\left(120 \mathrm{~cm}^{3}\right.$ tubes).

After 90 days of experimentation the variables number of shoots (NS), shoot fresh mass (SFM), shoot dry mass (SDM), plant cutting fresh mass (PCFM), plant cutting dry 
mass (PCDM), root fresh mass (RFM), root dry mass (RDM), total fresh mass (TFM), total dry mass (TDM) and, length of the largest root (LLR) were analyzed. The chemical analysis of the substrate solution ( $\mathrm{pH}$, electric conductivity, $\mathrm{P}, \mathrm{K}, \mathrm{Ca}$, $\mathrm{Mg}, \mathrm{S}, \mathrm{Na}, \mathrm{B}, \mathrm{Cu}, \mathrm{Mn}$ and $\mathrm{Zn}$ ) were analyzed according to the methodology of IN n ${ }^{\circ}$ 17/2007 (BRASIL, 2007).

The experimental design was a completely randomized block with 5 potting media and 2 croton varieties on a factorial scheme $5 \times 2$ (potting media $\times$ varieties), with 3 replicates, each plot having 10 cuttings set in individual tubes. Data were submitted to test of normality, heterogeneity and analysis of variance (ANOVA) and means were compared using the Tukey test at $5 \%$ probability with the Minitab 13.0 software.

\section{RESULTS AND DISCUSSION}

The croton cuttings cultivated in substrate PM2 (SSSB) did not root; thus, there were not data for the variables NS, SFM, SDM, RDM and LLR (Table 3).

Table 3. Characteristics of plant cutting from each variety of croton and potting media used as treatment.

\begin{tabular}{|c|c|c|c|c|c|c|c|c|c|c|}
\hline \multirow{3}{*}{$\begin{array}{l}\text { Potting } \\
\text { media }\end{array}$} & \multicolumn{2}{|c|}{ NS } & \multicolumn{2}{|c|}{ SFM } & \multicolumn{2}{|c|}{ SDM } & \multicolumn{2}{|c|}{ PCFM } & \multicolumn{2}{|c|}{ PCDM } \\
\hline & \multirow[b]{2}{*}{ Yellow } & \multirow[b]{2}{*}{ Red } & \multicolumn{8}{|c|}{ - } \\
\hline & & & Yellow & Red & Yellow & Red & Yellow & Red & Yellow & Red \\
\hline PM1 & $3.93 \mathrm{Aa}$ & $2.90 \mathrm{Aa}$ & $0.86 \mathrm{Ab}$ & $1.79 \mathrm{Aa}$ & $0.14 \mathrm{Aa}$ & $0.27 \mathrm{Ab}$ & $2.50 \mathrm{Ab}$ & $5.76 \mathrm{Aa}$ & $0.73 \mathrm{Ab}$ & $1.68 \mathrm{Aa}$ \\
\hline PM2 & $0.00 \mathrm{Bb}$ & $2.11 \mathrm{Aa}$ & $0.00 \mathrm{Ca}$ & $0.09 \mathrm{Ca}$ & $0.00 \mathrm{Ca}$ & $0.02 \mathrm{Ca}$ & $1.27 \mathrm{Ab}$ & $5.00 \mathrm{Aa}$ & $0.54 \mathrm{Ab}$ & $1.85 \mathrm{Aa}$ \\
\hline PM3 & $3.57 \mathrm{Aa}$ & $2.20 \mathrm{Aa}$ & $0.31 \mathrm{Bb}$ & $1.02 \mathrm{Ba}$ & $0.04 \mathrm{Bb}$ & $0.16 \mathrm{Ba}$ & $2.53 \mathrm{Ab}$ & $5.60 \mathrm{Aa}$ & $0.89 \mathrm{Ab}$ & $1.84 \mathrm{Aa}$ \\
\hline PM4 & $2.50 \mathrm{Aa}$ & $2.11 \mathrm{Aa}$ & $0.14 \mathrm{Ba}$ & $0.37 \mathrm{Ca}$ & $0.02 \mathrm{Ba}$ & $0.05 \mathrm{Ca}$ & $1.87 \mathrm{Ab}$ & $4.23 \mathrm{Ba}$ & $0.72 \mathrm{Ab}$ & $1.56 \mathrm{Aa}$ \\
\hline \multirow[t]{4}{*}{ PM5 } & $3.31 \mathrm{Aa}$ & $2.56 \mathrm{Aa}$ & $0.41 \mathrm{ABb}$ & $1.23 \mathrm{ABa}$ & $0.06 \mathrm{ABb}$ & $0.21 \mathrm{ABa}$ & $2.41 \mathrm{Ab}$ & $5.81 \mathrm{Aa}$ & $0.84 \mathrm{Ab}$ & $1.93 \mathrm{Aa}$ \\
\hline & \multicolumn{2}{|c|}{ RFM } & \multicolumn{2}{|c|}{ RDM } & \multicolumn{2}{|c|}{ TFM } & \multicolumn{2}{|c|}{ TDM } & \multicolumn{2}{|c|}{ LLR } \\
\hline & -- g -- & \multicolumn{9}{|c|}{$\mathbf{c m}$} \\
\hline & Yellow & Red & Yellow & Red & Yellow & Red & Yellow & Red & Yellow & Red \\
\hline PM1 & $0.67 \mathrm{Ab}$ & $1.05 \mathrm{Aa}$ & $0.05 \mathrm{Ab}$ & $0.07 \mathrm{Aa}$ & $4.03 \mathrm{Ab}$ & $8.59 \mathrm{Aa}$ & $0.92 \mathrm{Ab}$ & $2.02 \mathrm{Aa}$ & $7.60 \mathrm{Aa}$ & $7.49 \mathrm{Aa}$ \\
\hline PM2 & $0.00 \mathrm{Ba}$ & $0.00 \mathrm{Ca}$ & $0.00 \mathrm{Ba}$ & $0.00 \mathrm{Ca}$ & $1.27 \mathrm{Bb}$ & $5.03 \mathrm{Ca}$ & $0.54 \mathrm{Ab}$ & $1.86 \mathrm{Aa}$ & $0.00 \mathrm{Ba}$ & $0.00 \mathrm{Ba}$ \\
\hline PM3 & $0.13 \mathrm{Bb}$ & $0.59 \mathrm{Ba}$ & $0.00 \mathrm{Bb}$ & $0.04 \mathrm{Ba}$ & $2.87 \mathrm{Ab}$ & $6.60 \mathrm{Ba}$ & $0.93 \mathrm{Ab}$ & $1.98 \mathrm{Aa}$ & $6.42 \mathrm{Aa}$ & $7.24 \mathrm{Aa}$ \\
\hline PM4 & $0.02 \mathrm{Ba}$ & $0.13 \mathrm{Ca}$ & $0.00 \mathrm{Ba}$ & $0.01 \mathrm{Ba}$ & $2.04 \mathrm{Bb}$ & $4.73 \mathrm{Ba}$ & $0.73 \mathrm{Ab}$ & $1.62 \mathrm{Aa}$ & $0.93 \mathrm{Ba}$ & $2.37 \mathrm{Ba}$ \\
\hline PM5 & $0.26 \mathrm{ABb}$ & $0.77 \mathrm{ABa}$ & $0.02 \mathrm{ABb}$ & $0.06 \mathrm{Aa}$ & $3.08 \mathrm{ABb}$ & $7.80 \mathrm{Aa}$ & $0.92 \mathrm{Ab}$ & $2.20 \mathrm{Aa}$ & $7.64 \mathrm{Aa}$ & $8.67 \mathrm{Aa}$ \\
\hline
\end{tabular}

PM1 - 100\% CS, PM2 - 100\% SSSB, PM3 - 50\% CS + 50\% SSSB, PM4 - 100\% SSEB, PM5 - 50\% CS + 50\% SSEB, CS: commercial substrate, SSSB: organic compost with sewage sludge + sugarcane bagasse, SSEB: organic compost with sewage sludge + eucalyptus bark, NS - number of shoots, SFM - shoot fresh mass, SDM - shoot dry mass, PCFM - plant cutting fresh mass, PCDM - plant cutting dry mass, RFM - root fresh mass, RDM - root dry mass, TFM - total fresh mass, TDM - total dry mass, LLR - length of the largest root.

Means followed by the same letters, lowercase in rows and uppercase in columns, do not differ amongst themselves $(p \leq 0.05)$ by Tukey's test.

The red variety, unlike the yellow variety sprouted in PM2 (SSSB); however, there was no root system formation to support the cuttings (Table 3). The yellow and red croton varieties showed to be sensible of to the use of organic compost of sewage sludge (PM2 and PM4). The use of compost with sewage sludge used in the commercial production of container grown nursery crops (flowering annuals, herbaceous perennials and woody ornamentals) was tested and the optimal plant growth generally occurred in media containing 50 and 100 percent compost (BUGBEE, 2013).

The highest root dry mass (RDM) was obtained on substrates PM1 (CS) and PM5 (50\% CS + 50\% SSEB), while the other substrates did not show significant difference for the variable. The total dry mass was similar among the substrates, even so the red croton variety showed higher values. The plants total mass (TFM and TDM) was composed by the mass of the cuttings (PCFM and PCDM); thus, showed the same characteristics.

The commercial substrate (PM1) as well as the potting media PM3 (50\% CS + 50\% SSSB) and PM5 (50\% CS $+50 \%$ SSEB) had the best results for croton growth and development. The length of the largest root (LLR) was higher on PM1 (CS), PM3 (50\% CS + 50\% SSSB) and PM5 (50\% CS $+50 \%$ SSEB) for both varieties and mass of roots (RFM and RDM) were higher on PM1 (CS) and PM5 $(50 \% \mathrm{CS}+50 \% \mathrm{SSEB})$ for both varieties.

The croton varieties differed statistically for some plants characteristics according to the potting media. The mass of roots and shoot had the same performance, with the highest values on PM1 (CS), PM3 (50\% CS + 50\% $\mathrm{SSSB})$ and PM5 (50\% CS + 50\% SSEB) for the red variety. 
However, the length of the largest root (LLR) had no significant difference among varieties for all potting media. Rooting of croton cuttings depends of substrate; substrate with low density, high CTC and air spaces as medium grade vermiculite medium was the most suitable for the rooting while soil and sand presented the lowest rooting rates (TILLMAN et al., 1994).

The potting media have chemical and physical characteristics, which interfere on plant development. The potting media must have the $\mathrm{pH}$ close to neutrality, nutrient concentration sufficient for the initial growth of the plants; have a good relation between water retention and drainage, and porosity that allows root system formation.

Chemical analyzes of the solution in equilibrium of the substrate (substrate solution) were carried out to characterize the nutrient availability at the beginning of the experiment (without plant intervention) and at the end of the experiment, when the plants completed 90 days in the nursery (to verify the interference of plants in nutrients levels for each substrate studied). The chemical analyzes were performed to characterize only the two instants; however, the concentration of nutrients in the substrate solution fluctuates over time, since they are constantly adsorbed and accessible. Thus, the values of analyzes demonstrate the behavior of each nutrient in the substrate solution on that moment, thus not what is adsorbed in the substrate.

During the experimentation, the composition of the substrate solution may have altered according to external influences (temperature, humidity) and internal influences (plant absorption, leaching, CTC). Some values of the final chemical analysis of substrates solutions showed an increase when compared with the initial chemical analysis. These results may have taken place by three hypotheses: some nutrients were available for the substrate solution over time increasing their concentration; decomposition of the organic material in the potting media initiating an increase of the amount of mineralized nutrients available to plants, or the decomposition of larger particles into smaller particles increasing the density of the material and consequently the amount of material to be analyzed once the analysis was performed based on sample's volume. Since there were no nutrients incoming into the system through fertilization, the exit of nutrients were only carried out by plant absorption or leaching. However, leaching was controlled using a nebulization system for irrigation; thus, most of the nutrient output of the system was performed via absorption of croton plants.

The values in Table 4 represent what availability of nutrients at that time in substrate solution and not what is adsorbed at CTC or still unavailable on organic form. Thus, the chemical constitution of the substrate solution was different over time, according to nutrient availability, nutrient absorption by plants or loss by leaching.

At $90^{\text {th }}$ days the $\mathrm{pH}$ of substrates solutions PM2 (SSSB) and PM4 (SSEB) was higher than PM1 (CS), PM3 (50\% $\mathrm{CS}+50 \% \mathrm{SSSB})$ and PM5 (50\% CS $+50 \%$ SSEB) (Table 4). The $\mathrm{pH}$ values of all potting media were between 5.5 and 6.5, which are adequate for ornamental crops (WALDEMAR, 2000); however, they are higher than on organic substrates (5.2 to 5.5).

The potting media PM4 (SSEB) had higher CE value and $\mathrm{K}, \mathrm{Ca}, \mathrm{Mg}$ and $\mathrm{S}$ contents in the final substrate solution; however, the cuttings did not root well. Consequently, the high concentration of nutrients at the end occurred by the non-absorption by plants. The highest values of $\mathrm{P}$ were observed in PM1 (CS).

Soluble salt concentrations of substrates increase as a function of sludge amendment and were within the range that can inhibit the growth of many plant species at the high levels of sludge application (RODGERS and ANDERSON, 1995). However, this was not the case, once the commercial substrate (PM1) had highest EC value (Table 1). The highest concentrations of some nutrients in PM1 (CS) at the initial analysis of the substrate solution results of the addition of soluble minerals at the moment of fertilizer production, i.e., readily available nutrients.

Commercial substrates have also vermiculite in its composition, which has a high CTC, providing adsorption of ions and consequent their release over time; thus, there is storage of part of the nutrients that are gradually available to plants. In general, the concentration of nutrients in substrates solutions decrease at 90 days (end of the rooting period), and the rate of decrease of each nutrient being similar between the croton varieties, implication that nutrient absorption by croton plants and/or it loss by leaching were similar. 
Table 4. Chemical characteristics of samples at the end of the 90 days from each potting media used as treatment for each croton variety.

\begin{tabular}{|c|c|c|c|c|c|c|c|c|c|c|c|c|c|c|}
\hline \multirow{3}{*}{$\begin{array}{l}\text { Potting } \\
\text { media }\end{array}$} & \multicolumn{2}{|c|}{ pH } & \multirow{2}{*}{\multicolumn{2}{|c|}{ 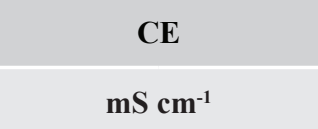 }} & \multicolumn{2}{|c|}{$\mathbf{P}$} & \multicolumn{2}{|c|}{$\mathbf{K}$} & \multicolumn{2}{|c|}{$\mathrm{Ca}$} & \multicolumn{2}{|c|}{ Mg } & \multicolumn{2}{|c|}{$\mathbf{S}$} \\
\hline & \multirow[b]{2}{*}{ Yellow } & \multirow[b]{2}{*}{ Red } & & & \multicolumn{10}{|c|}{ - } \\
\hline & & & Yellow & Red & Yellow & Red & Yellow & Red & Yellow & Red & Yellow & Red & Yellow & Red \\
\hline PM1 & $5.8 \mathrm{BCa}$ & $5.7 \mathrm{Ba}$ & $0.23 \mathrm{Ca}$ & $0.16 \mathrm{BCb}$ & $7.0 \mathrm{Aa}$ & $5.3 \mathrm{Ab}$ & $27.6 \mathrm{Aa}$ & $18.3 \mathrm{Bb}$ & $7.0 \mathrm{Ca}$ & $5.0 \mathrm{Ba}$ & $5.7 \mathrm{BCa}$ & $3.6 \mathrm{BCb}$ & $2.6 \mathrm{Ca}$ & $0.7 \mathrm{Ba}$ \\
\hline PM2 & $6.1 \mathrm{Ab}$ & $6.4 \mathrm{Aa}$ & $0.15 \mathrm{Da}$ & $0.13 \mathrm{Ca}$ & $1.3 \mathrm{BCa}$ & $1.5 \mathrm{Ba}$ & $9.5 \mathrm{Da}$ & $9.3 \mathrm{Da}$ & $9.6 \mathrm{Ca}$ & $6.3 \mathrm{Ba}$ & $2.4 \mathrm{Ca}$ & $1.3 \mathrm{Ca}$ & $8.9 \mathrm{Ca}$ & 19.1 Ba \\
\hline PM3 & $5.4 \mathrm{CDa}$ & $5.5 \mathrm{Ba}$ & $0.22 \mathrm{Ca}$ & $0.21 \mathrm{Ba}$ & $1.7 \mathrm{Ba}$ & $1.7 \mathrm{Ba}$ & $15.2 \mathrm{Ca}$ & $13.5 \mathrm{Ca}$ & $11.7 \mathrm{Ca}$ & $10.7 \mathrm{Ba}$ & $5.1 \mathrm{Ba}$ & $4.1 \mathrm{Ba}$ & $2.0 \mathrm{Ca}$ & $5.4 \mathrm{Ba}$ \\
\hline PM4 & $5.8 \mathrm{ABa}$ & $5.6 \mathrm{Ba}$ & $0.82 \mathrm{Aa}$ & $0.93 \mathrm{Aa}$ & $0.3 \mathrm{Da}$ & $0.5 \mathrm{Ca}$ & $20.9 \mathrm{Bb}$ & $25.6 \mathrm{Aa}$ & $100.1 \mathrm{Ab}$ & 132.7 Aa & $12.3 \mathrm{Ab}$ & 14.4 Aa & $179.5 \mathrm{Aa}$ & $295.0 \mathrm{Ab}$ \\
\hline \multirow[t]{4}{*}{ PM5 } & $5.4 \mathrm{Cb}$ & $5.7 \mathrm{Ba}$ & $0.44 \mathrm{Ba}$ & $0.18 \mathrm{BCb}$ & $0.9 \mathrm{CDa}$ & $1.3 \mathrm{Ba}$ & $22.7 \mathrm{Ba}$ & $12.1 \mathrm{CDb}$ & $37.5 \mathrm{Ba}$ & $10.8 \mathrm{Bb}$ & $10.3 \mathrm{Aa}$ & $2.8 \mathrm{BCb}$ & $47.7 \mathrm{Ba}$ & $13.0 \mathrm{Bb}$ \\
\hline & \multicolumn{2}{|c|}{$\mathrm{Na}$} & \multicolumn{2}{|c|}{ B } & \multicolumn{2}{|c|}{$\mathrm{Cu}$} & \multicolumn{2}{|c|}{$\mathrm{Fe}$} & \multicolumn{2}{|c|}{ Mn } & \multicolumn{2}{|c|}{ Zn } & & \\
\hline & & - & $-\mathrm{mg} \mathrm{L}^{-1}$ & - & 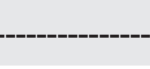 & 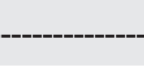 & 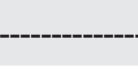 & 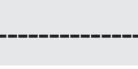 & & & \\
\hline & Yellow & Red & Yellow & Red & Yellow & Red & Yellow & Red & Yellow & Red & Yellow & Red & & \\
\hline PM1 & $12.4 \mathrm{Aa}$ & $10.0 \mathrm{Ba}$ & $0.06 \mathrm{ABa}$ & $0.05 \mathrm{Bb}$ & $0.02 \mathrm{ABa}$ & $0.01 \mathrm{Bb}$ & $0.17 \mathrm{Ba}$ & $0.21 \mathrm{Ba}$ & $0.03 \mathrm{Ca}$ & $0.01 \mathrm{Ca}$ & $0.06 \mathrm{Ba}$ & $0.02 \mathrm{Cb}$ & & \\
\hline PM2 & $11.3 \mathrm{Aa}$ & $10.7 \mathrm{Ba}$ & $0.04 \mathrm{CDa}$ & $0.04 \mathrm{Ba}$ & $0.03 \mathrm{Aa}$ & $0.03 \mathrm{Aa}$ & $2.56 \mathrm{Ab}$ & $3.61 \mathrm{Aa}$ & $0.05 \mathrm{Ca}$ & $0.04 \mathrm{Ca}$ & $0.08 \mathrm{Ba}$ & $0.09 \mathrm{Ba}$ & & \\
\hline PM3 & $10.7 \mathrm{Aa}$ & $12.4 \mathrm{Ba}$ & $0.03 \mathrm{Da}$ & $0.03 \mathrm{Ca}$ & $0.01 \mathrm{Ba}$ & $0.01 \mathrm{Ba}$ & $0.18 \mathrm{Ba}$ & $0.20 \mathrm{Ba}$ & $0.12 \mathrm{Ba}$ & $0.11 \mathrm{Ba}$ & $0.09 \mathrm{Ba}$ & $0.09 \mathrm{Ba}$ & & \\
\hline PM4 & $12.7 \mathrm{Ab}$ & $17.7 \mathrm{Aa}$ & $0.05 \mathrm{BCb}$ & $0.07 \mathrm{Aa}$ & $0.01 \mathrm{Ba}$ & $0.02 \mathrm{Ba}$ & $0.08 \mathrm{Ba}$ & $0.93 \mathrm{Ba}$ & $0.23 \mathrm{Ab}$ & $0.41 \mathrm{Aa}$ & $0.14 \mathrm{Ab}$ & $0.21 \mathrm{Aa}$ & & \\
\hline PM5 & $12.0 \mathrm{Aa}$ & $12.9 \mathrm{Ba}$ & $0.07 \mathrm{Aa}$ & $0.04 \mathrm{Bb}$ & $0.02 \mathrm{ABa}$ & $0.01 \mathrm{Ba}$ & $0.29 \mathrm{Ba}$ & $1.25 \mathrm{Ba}$ & $0.25 \mathrm{Aa}$ & $0.05 \mathrm{Cb}$ & $0.16 \mathrm{Aa}$ & $0.06 \mathrm{BCb}$ & & \\
\hline
\end{tabular}

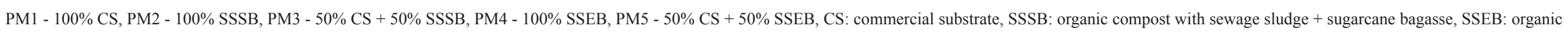
compost with sewage sludge + eucalyptus bark.

Means followed by the same letters, lowercase in rows and uppercase in columns, do not differ amongst themselves $(p \leq 0.05)$ by Tukey's test. 


\section{CONCLUSIONS}

Sewage sludge compost with sugarcane bagasse or eucalyptus bark can be used as a substrate for rooting and growth of croton cuttings when mixed on $1: 1 \mathrm{~V} \mathrm{~V}^{-1}$ ratio with commercial substrate.

The use of the pure sewage sludge compound with sugarcane bagasse or eucalyptus bark prejudiced croton cuttings to root.

\section{AUTHORS CONTRIBUTIONS}

M.C.L. (10000-0001-7220-2945: conception and design of the research, obtaining, analyze and interpretation of data, wrote and critically analyses of manuscript. C.M.D.M. (D)0000-0003-2848-6340: conception and design of the research, analyze and interpretation of the data, wrote and critically analyses of manuscript. D.A.S.A. (D0000-0003-1196-481x: obtaining data, analyze and interpretation of the data, wrote and critically analyses of manuscript. A.R.T. (D00000001-6006-4741: statistical analysis, analyze and interpretation of the data, wrote and critically analyses of manuscript and translation. L.V.C.S.: analyze and interpretation of the data, wrote and critically analyses of manuscript. R.L.V.B. (D00000001-7516-4147: conception and design of the research, analyze and interpretation of the data, wrote and critically analyses of manuscript and financial and obtaining funding.

\section{REFERENCES}

BRASIL. Instrução Normativa MAPA n ${ }^{\circ} 25$, de 23 de julho de 2009. Estabelece normas sobre as especificações e as garantias, as tolerâncias, o registro, a embalagem e a rotulagem dos fertilizantes orgânicos simples, mistos, compostos, organominerais e biofertilizantes destinados à agricultura. Brasília: Diário Oficial da República Federativa do Brasil, 2009.

BRASIL. Ministério da Agricultura, Pecuária e Abastecimento. Instrução Normativa SDA n⿳0 17, de 21 de maio 2007. Diário Oficial da União, Brasília, DF, 24 mai. 2007. Seção 1.

BRASIL. Resolução CONAMA n ${ }^{\circ}$ 375, de 29 de agosto de 2006. Define critérios e procedimentos, para o uso agrícola de lodos em estações de tratamento de esgoto sanitário e seus produtos derivados, e dá outras providências. Brasília: Diário Oficial da República Federativa do Brasil, 2006.

BRASIL. Resolução CONAMA n 380, de 31 de outubro de 2006. Retifica o anexo 1 da Resolução CONAMA 375/06. Brasília: Diário Oficial da República Federativa do Brasil, 2006.
BRASIL. Resolução CONAMA n ${ }^{\circ} 481$, de 3 de outubro de 2017. Estabelece critérios e procedimentos para garantir o controle e a qualidade ambiental do processo de compostagem de resíduos orgânicos, e dá outras providências. Brasília: Diário Oficial da República Federativa do Brasil, 2017.

BUGBEE, G.J. Growth of ornamental plants in container media amended with biosolids compost. Compost Science \& Utilization, v.10, n.2, p.92-98, 2013. DOI: $10.1080 / 1065657 X .2002 .10702069$

CONTIN, M.; GOI, D.; DE NOBILI, M. Land application of aerobic sewage sludge does not impair methane oxidation rates of soils. Science of the Total Environment, v.441, p.10-18, 2012. DOI: 10.1016/j.scitotenv.2012.09.052

GALDOS, M.V.; DE MARIA, I.C.; CAMARGO, O.A. Atributos químicos e produção de milho em um Latossolo Vermelho Eutroférrico tratado com lodo de esgoto. Revista Brasileira de Ciências do Solo, v.28 p.569-577, 2004. DOI; http://dx.doi.org/10.1590/S0100-06832004000300017

HONG-TAO, L.; DING, G.; TONG-BIN, C.; HONG, C.; GUO-DI, Z. Improvement of salinity in sewage sludge compost prior to its utilization as nursery substrate. Journal of the Air \& Waste Management Association, v.64, n.5, p.546-551, 2014. DOI: 10.1080/10962247.2013.872710

MAGDALITA, P.M., TORRETA, N.K.; SOTTO, R.C. Characterization of phenotypic variation in selected Croton [Codiaeum variegatum (L.) Rhumph. ex A. Juss.] varieties and natural mutants. Journal of Nature Studies, v.13, n.2, p.41-55, 2014.

MAHESH,Y.S.;SHANKARAPPA,K.S.;RANGASWAMY, K.T.; PRAMEELA, H.A.; ASWATHANARAYANA, D.S.; DIVYA, B.L.; NAGESHA, N.; MARUTHI, M.N. Detection and characterization of a begomovirus associated with leaf curl disease of ornamental croton (Codiaeum variegatum). The Journal of Horticultural Science and Biotechnology, v.85, n.2, p.101-105, 2010. DOI: https:// doi.org/10.1080/14620316.2010.11512638

PRADO, A.K; CUNHA, M.E.T. Efeito da aplicação de lodo de esgoto e curtume nas características físico-químicas do solo e na absorção de nitrogênio por feijoeiro (Phaseolus vulgaris L.). UNOPAR Científica Ciências Exatas e Tecnológicas, v.10, n.1, p.37-41, 2011.

RODGERS, C.S.; ANDERSON, R.C. Plant growth inhibition by soluble salts in sewage sludge-amended mine spoils. Journal of Environmental Quality, v.24, n.4, p.627-630, 1995.

SILVA, H.P.; JUNIOR, D.D.S.B.; NEVES, J.M.G.; SAMPAIO, R.A.; DUARTE, R.F. Qualidade física de sementes de girassol produzido sob doses de lodo de esgoto. Revista Verde, v.5, n.1, p.1-6, 2010. 
SINGH, R.P., AGRAWAL, M. Potential benefits and risks of land application of sewage sludge. Waste Management, v.28, p.347-58, 2008. DOI: 10.1016/j.wasman.2006.12.010

TILLMANN, M.A.A.; CAVARIANI, C.; PIANA, Z.; MINAMI, K. Comparação entre diversos substratos no enraizamento de estacas de crotón (Codiaeum variegatum L.). Scientia Agricola, v.51, n.1, p.17-20, 1994). DOI: https://dx.doi.org/10.1590/S0103-90161994000100003

WALDEMAR, C.C. A experiência do DMLU como fornecedor de resíduos úteis na composição de substratos para plantas. In: KÄMPF, A.N.; FERMINO, M.H. (ed.) Substrato para plantas: a base da produção vegetal em recipientes. Porto Alegre: Gênesis, 2000. p.171-176.
WILSON, S.C.; DUARTE-DAVIDSON, R.; JONES, K.C. Screening the environment fate of organic contaminants in sewage sludges applied to agricultural soil: 1 . The potential for downward movement to ground waters. Science of Total Environment, v.185, p. 45-57, 1996.

YOUNIS, A.; RIAZ, A.; WASEEM, M.; KHAN, M.A.; NADEEM, M. Production of quality croton (Codiaeum variegatum) plants by using different growing media. American-Eurasian Journal of Agricultural and Environmental Science, v.7, n.2, p.232-237, 2010. 